\title{
ENHANCING BIOGAS PRODUCTION BY THERMAL PRETREATMENT OF AGRICULTURAL WASTES
}

\author{
Kishta, A. M. ; Reham S. Faidallah ${ }^{* *}$ and A. Awny ${ }^{* * *}$ \\ ABSTRACT
}

Developing countries are suffering from many problems such as shortage in energy and electricity in addition to increasing wastes that cause high pollution. Biogas production is gaining increasing attention worldwide to avoid global warming, increasing energy security and the need for sustainable waste management. So the aim of the present study was enhancement of biogas production by using thermal pretreatment for the agricultural wastes. A laboratory scale bioreactor made from plastic, 8 liter capacity, was used in this research. Three different mixtures were used (100\% cattle dung (CD), 50\% CD + 50\% BS, and 100\% bagasse (BS)). The samples were heated in a furnace at $175^{\circ} \mathrm{C}$, and $200{ }^{\circ} \mathrm{C}$. The samples were subjected to heat for three different durations 20, 40 or 60 min. Also samples were partially heated at four levels, 25\%, 50\%, 75\% and $100 \%$. The results indicated that the maximum daily biogas production, accumulative biogas production and methane production related to volatile solids mass (VS) were $732.4,15475.5 \mathrm{~L} / \mathrm{kg} \mathrm{VS}$, and $577.9 \mathrm{LCH}_{4} / \mathrm{Kg}$ VS respectively for the second fermentation mixture $(50 \%$ $\mathrm{CD}+50 \% \mathrm{BS}$ ) and $60 \mathrm{~min}$ heating time using temperature of $175^{\circ} \mathrm{C}$. But the maximum calorific value was $7241.7 \mathrm{kCal} / \mathrm{m}^{3}$ for the third fermentation mixture $(100 \% \mathrm{BS})$ using temperature of $200{ }^{\circ} \mathrm{C}$ for $60 \mathrm{~min}$ and $100 \%$ heating of samples.

Keywords: Biogas, thermal pretreatment, bagasse, heating time, methane production, calorific value.

\section{INTRODUCTION}

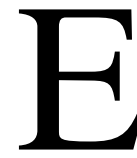
gypt generates huge amounts of farm wastes yearly. The removal of those wastes is a major concern and considered one of critical environmental challenges. Those wastes have coarse plant byproducts, farm yard manure, perished fruits and vegetables, and other wastes which chemically low in protein and fat contents.

*Assistant Professor, Dept. of Agric. Engineering, Faculty of Agriculture, Zagazig University, Zagazig, Egypt.

**Lecturer, Dept. of Agric. Engineering, Faculty of Agriculture, Zagazig University, Zagazig, Egypt. 
Most of farm wastes are high in lignin and cellulose contents. In addition, energy demand is increasing rapidly worldwide and resulted in a rapid depletion of fossil fuel resources. It is of great importance to find other sources of clean energy that cause minimal damage to the environment and reduce the greenhouse gases (GHGs) emission to the atmosphere (IPCC 2000).

Biogas generated by digestion has been proven to be the most energy efficient and environmentally beneficial technology for bioenergy production (Fehrenbach et al. 2008). Anaerobic digestion (AD) is used to produce biogas. $\mathrm{AD}$ is a biochemical process where different types of anaerobic microorganisms decompose complex organic matter (biomass) to smaller components, in the absence of oxygen. Biogas is not a pure chemical substance. It consists of 50-70\% methane, 30-50\% carbon dioxide and other minor ingredients such as, ammonia, hydrogen sulfide, siloxane and halides (Bakhov et al. 2014). The proportion of each of these components depends on the ingredients of the raw substrates and the process setting used during the digestion (Bond and Templeton, 2011). Methane content is the limiting factor of biogas calorific value. One cubic meter of biogas contains $60 \%$ methane with calorific value of $21.5 \mathrm{MJ}$ equivalents to $5.97 \mathrm{kWh}$ of electricity at standard temperature and pressure (STP).

The procedure of anaerobic digestion occurs through four progressive stages: hydrolysis, acidogenesis, acetogenesis, and methanogenesis. The anaerobic digestion process is reliant on the cooperation between the different microorganisms that can complete the four previously mentioned stages. However, some substrates are decomposed very slowly due to the inhibitive effect of some of their chemicals to the growth and activity of the microorganisms. Also, their molecular configuration is intricate to the degree that microorganisms and their enzymes become unable to decompose (Montgomery and Bochmann 2014). To overcome some of these problems and increase degradability of complex molecules such as sugars and lignocelluloses, various chemical, mechanical and thermal pretreatment technologies have been developed. Those techniques include but not limited to thermal treatments and enzymatic processes. In thermal pretreatment, the wastes are heated (on average 125 
to $220{ }^{\circ} \mathrm{C}$ ) under pressure and kept at that temperature for the desired time. This can be conducted with autoclaves, ovens or microwave devices. Water must be added to dry wastes before thermal treatment to prevent the hydrogen bonds that linked with crystalline cellulose and the lignocelluloses complexes, causing the biomass to swell (Garrote $\boldsymbol{e t}$ al. 1999). Several investigators stated that heating of wastes before anaerobic digestion has improved methane production and volatile solids reduction (Bharathiraja et al. 2018). Many studies stated that the optimal thermal range of $160-180{ }^{\circ} \mathrm{C}$ was suitable for hydrolysis of wastes to increase methane production during anaerobic digestion (Jayashree $\boldsymbol{e t}$ al. 2014). Qiao et al. (2011) conducted several experiments that include thermal preheating at $170{ }^{\circ} \mathrm{C}$ for one hour. They reported that the biogas production increased significantly for different substrates used in the study. Bougrier et al. (2008) classified thermal pretreatment into two groups. The first used temperatures between 70 and $121{ }^{\circ} \mathrm{C}$ led to enhancing biogas yield about $20-30 \%$. The second group is between $160-$ $180{ }^{\circ} \mathrm{C}$ which led to more biogas production enhancement.

Biogas is a form of renewable energy sources. Biogas is used for replacement of fossil fuels for power and heat production purposes. Also, it can be used as gaseous vehicle fuel. Methane-rich biogas can be used instead of natural gas as a feedstock for producing chemicals and materials (Weiland 2010). So the aim of this study is to examine the effects of thermal pre-treatment by varying temperature, exposure time, and heated proportion of two farm wastes and their mixture on enhancement of biogas production, methane percentage, and calorific value.

\section{MATERIALS AND METHODS}

This study was carried out between June and August 2018 at Faculty of Veterinary Medicine, Zagazig University, Egypt to evaluate the influence of two heating temperatures as thermal pretreatments, three heating times and partial heating of substrate samples using two different agricultural wastes and their mixture on biogas production.

\section{Materials}

1.1. Two types of biomass lignocelluloses-rich, cattle dung (CD) and bagasse (BS) were used in this study. The bagasse wastes were fine 
ground into particles with an average size of $1.0 \mathrm{~mm}$ then the ground wastes were classified into three groups according to mixing ratio (A: $100 \% \mathrm{CD}, \mathrm{B}: 100 \% \mathrm{BS}$ and $\mathrm{C}: 50 \% \mathrm{CD}+50 \% \mathrm{BS}$ ) and analyzed for chemical characteristics as shown in Table (1). Bagasse components were determined as $39 \%$ cellulose, $25 \%$ hemicelluloses, $26 \%$ lignin, and $10 \%$ minerals and other components. The mixtures of organic wastes were mixed at a ratio of 1: $2 \mathrm{w} / \mathrm{w}$ with water to arrive at the desired solid content. Fresh rumen extract was used as a starter of anaerobic digestion.

Table 1: Chemical analysis of agricultural wastes used in the experements.

\begin{tabular}{|c|c|c|c|c|c|c|c|c|}
\hline & $\begin{array}{c}\text { Protein, } \\
\%\end{array}$ & $\begin{array}{c}\mathrm{N}, \\
\%\end{array}$ & $\mathrm{C} / \mathrm{N}$ & $\mathrm{pH}$ & $\begin{array}{l}\mathrm{ASH}, \\
\%\end{array}$ & $\begin{array}{l}\mathrm{TVS}, \\
\%\end{array}$ & $\begin{array}{c}\mathrm{TMC}, \\
\%\end{array}$ & $\begin{array}{c}\mathrm{TS}, \\
\%\end{array}$ \\
\hline $\begin{array}{c}\text { Cattle Dung } \\
(\mathrm{CD})\end{array}$ & 13 & 2.5 & 29 & 6.9 & 14.1 & 85.9 & 87.9 & 12.1 \\
\hline $\begin{array}{c}\text { Bagasse } \\
(\mathrm{BS})\end{array}$ & 7.5 & 1.1 & 31 & 6.6 & 16.8 & 83.2 & 84.5 & 15.5 \\
\hline $\begin{array}{c}\text { Mixture } \\
(50 \% \text { CD + } \\
50 \% \text { BS })\end{array}$ & 11.7 & 1.9 & 30 & 6.7 & 15.9 & 84.1 & 86.4 & 13.6 \\
\hline Starter & 29 & 4.3 & 20 & 6.8 & 37.2 & 62.8 & 90.2 & 9.8 \\
\hline
\end{tabular}

TVS $=$ Total Volatile Solids, $\mathbf{T M C}=$ Total Moisture content , and TS $=$ Total Solids .

1.2. A number of laboratory scale bioreactors used in this research. They were 8 liter capacity plastic prototype reactors as shown in Fig.1, with 6 liter as a filling volume and 2 liter as a headspace volume. Each reactor was connected with a plastic tube with diameter of 0.5 $\mathrm{cm}$ just above the slurry. After the fermentation started, the gas bubbled up entering the tube which led to a flask that half filled with a brine solution to work as pressure regulator. The end of the tube was immersed near the bottom of the flask. Another tube exiting from the top of the flask connected the flask to the gas collection setup. The gas collection setup consisted of a water path and an inverted graduated cylinder of 10 litter capacity filled with water. The tube is inserted under the inverted cylinder so the gas would bubble up displaces a volume of water equivalent to the volume of biogas produced.

1.3. Top loading balance (50kg "Five goat" model Z051599), Digital $\mathrm{pH}$ meter, thermometer, electric oven and electric muffle were used with all experiments. 


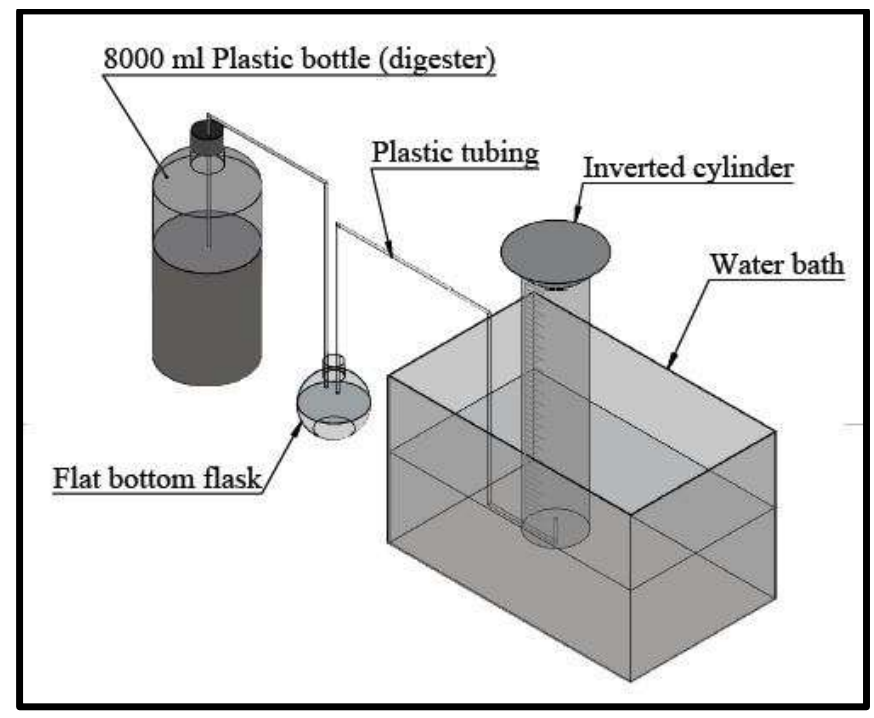

\section{Methods}

Figure 1: Schematic diagram of the experiment layout.

\subsection{Experimental conditions}

All experiments were conducted under the following parameters:

- Three different fermentation substrates, $100 \%$ CD, $100 \%$ BS, and $50 \% \mathrm{CD}+50 \% \mathrm{BS}$.

- Two different temperatures of $\left(175\right.$ and $\left.200{ }^{\circ} \mathrm{C}\right)$ as a thermal pretreatment.

- Three different durations of thermal pretreatment (20, 40 and 60 $\min )$.

- Four different levels of wastes partial heating $(25 \%, 50 \%, 75 \%$ and $100 \%)$.

\subsection{Thermal pretreatment}

The mixed waste samples were put in 2 liter tempered glass flask and mixed with distilled water at ratio 1: $4 \mathrm{w} / \mathrm{w}$ to prevent dry biomass from burning during pretreatment. The flasks were covered by aluminum foil and put in a high temperature furnace (Model SX-5-12, made in China). The temperature regulator was set at 175 and $200{ }^{\circ} \mathrm{C}$. The temperature increased gradually until reached the set point. Once temperature was reached the set point, the furnace was held for the selected durations of time (20, 40 or $60 \mathrm{~min}$ ) for each temperature of thermal pretreatment. After the different pretreatments were carried out, the flasks were 
collected from the furnace and left to cool down at room temperature. The pretreated samples at different temperatures were placed in the bioreactors with distilled water at a ratio $1: 2 \mathrm{w} / \mathrm{w}$.

\subsection{Analysis and calculations}

Standard analytical methods (Tran, 2017) were employed to determine total solids (TS), volatile solids (VS) and total Kjeldahl nitrogen (TKN) of sugar cane bagasse and cattle dung before pretreatment. Total organic carbon (TOC\%) was calculated by dividing the value of volatile solid content (VS\%) by 1.8 according to Adams et al., 1951. Produced biogas was measured by a wetted displacement method according to Gosch $\boldsymbol{e t}$ al. (1983)

\subsection{Measurements}

All treatments were evaluated taking into consideration the following indicators:

\subsubsection{Daily biogas production}

The volume of produced biogas was equal to the volume of displaced water from the inverted graduated transparent $10 \mathrm{~L}$ plastic cylinder as used by Gosch $\boldsymbol{e t}$ al. (1983) then corrected to account for temperature variations using the following equation:

$V=\frac{V_{m} \cdot \mathrm{T}}{\mathrm{T}_{\mathrm{m}}}$

Where: V: biogas volume at $\mathrm{STP}, \mathrm{ml}, \mathrm{V}_{\mathrm{m}}$ : biogas volume at room temperature, $\mathrm{ml}$, $\mathrm{T}$ : standard temperature, $0{ }^{\circ} \mathrm{C}\left(273^{\circ} \mathrm{K}\right)$, and $\mathrm{T}_{\mathrm{m}}$ : room temperature in ${ }^{\circ} \mathrm{K}$.

The following equation was used to estimate biogas production based on the amount of volatile solids consumed per day:

$V_{B G}=m_{V S} \times Y_{B G}$

Where $\mathrm{V}_{\mathrm{BG}}$ : is the estimated biogas production rate associated with feed material $\left(\mathrm{m}^{3}\right.$ biogas/day), $\mathrm{m}_{\mathrm{Vs}}$ : is the mass flow rate of volatile solids contained in feed material ( $\mathrm{kg}$ volatile solid/day), and $\mathrm{Y}_{\mathrm{BG}}$ : is the biogas yield of feed material $\left(\mathrm{m}^{3}\right.$ biogas $/ \mathrm{kg}$ volatile solid).

\subsubsection{Methane and carbon dioxide content}

The volumes of $\mathrm{CH}_{4}$ and $\mathrm{CO}_{2}$ in biogas were estimated by the concentrated alkaline absorption method using the potassium hydroxide (KOH, 40\%). The $\mathrm{KOH}$ device consists of glass U-tube shaped with 12 
$\mathrm{mm}$ internal diameter filled with $\mathrm{KOH}$ (Ezekoye and Okek, 2006). The U-tube attached with tap in order to adjust the solution level with atmospheric pressure after $\mathrm{CO}_{2}$ removal. The tube was installed with samples injection as a biogas inlet and with gas outlet to release gases after $\mathrm{CO}_{2}$ removal. The percentage of $\mathrm{CO}_{2}$ in biogas was calculated as follows:

$\mathrm{CO}_{2} \%=\frac{V_{1}-V_{2}}{V_{1}} \times 100,($ Abdel-Hadi and Abd El-Azeem 2008).

Where $\mathrm{V}_{1}$ : biogas volume before removal of $\mathrm{CO}_{2}, \mathrm{ml}$, and $\mathrm{V}_{2}$ : volume of the other gases after removal of $\mathrm{CO}_{2}, \mathrm{ml}$.

$\mathbf{C H}_{\mathbf{4}} \%=\mathbf{1 0 0} \%-\left[\mathbf{C O}_{\mathbf{2}} \%+\mathbf{3} \%\left(\mathrm{H}_{\mathbf{2}} \boldsymbol{S}\right.\right.$ and other Gases Vol. $\left.)\right], \quad$ (AbdelHadi and Abd El-Azeem 2008). Where: $3 \%$ is the average content of $\mathrm{H}_{2} \mathrm{~S}$ and other gases in biogas corresponding to (GTZ, 1999).

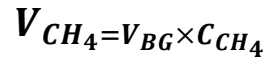

Where: $\mathbf{V}_{\mathbf{C H} 4}$ is the methane production rate of feed material $\left(\mathrm{m}^{3}\right.$ $\mathrm{CH}_{4} /$ day), and $\mathbf{C}_{\mathbf{C H} 4}$ is the biogas content associated with feed material.

\subsubsection{Calculation of Calorific Value (CV) of Biogas}

Calorific value of biogas depends on many factors which are mainly the percentage of methane, moisture content and temperature.

$\mathrm{CV}$ of biogas $=\mathrm{CV}$ of pure methane $\times$ methane percentage.

Where, $\mathrm{CV}$ of pure methane $=8560 \mathrm{kCal} / \mathrm{m}^{3}$, (Salunkhe et al. 2012)

\section{RESULTS AND DISCUSSION}

The biogas production from each treatment was measured daily and the accumulative biogas production was obtained from summing out the daily production. It is interesting to notice the difference in results for different treatments on short and long-term runs of the experiments.

\section{Table 2: Results summary for control treatments.}

\begin{tabular}{|l|c|c|c|c|}
\hline $\begin{array}{l}\text { Type of } \\
\text { substrate }\end{array}$ & $\begin{array}{c}\text { Daily } \\
\text { Biogas } \\
\text { Production, } \\
\text { L/kg VS }\end{array}$ & $\begin{array}{c}\text { Accumulative } \\
\text { Biogas } \\
\text { Production, } \\
\text { L/kg VS }\end{array}$ & $\begin{array}{c}\text { Methane } \\
\text { production, } \\
\text { L/kg VS }\end{array}$ & $\begin{array}{c}\text { Calorific } \\
\text { Value } \\
\mathrm{kCal} / \mathrm{m}^{3}\end{array}$ \\
\hline 100\% C.D. & 258.5 & 4280.0 & 162.4 & 5392.8 \\
\hline $\begin{array}{l}50 \% \text { C.D. } \\
+50 \text { BS }\end{array}$ & 291.0 & 4630.0 & 189.0 & 5564.0 \\
\hline $100 \%$ BS & 216.3 & 4020.0 & 151.8 & 5992.0 \\
\hline
\end{tabular}


The control treatments (no heating) results are shown in Table 2. It is visible that the mixed substrate gave the highest daily and accumulative biogas production, while the pure bagasse gave the highest calorific value of produced biogas due to the increased content of methane. The results summarized in Table 2 will be used as a basis for comparison throughout the discussion. The retention time (duration from start to end date) varied slightly among different substrates used in the experiments. The $100 \%$ cattle dung treatments took 31 day but the mixed (50\% cattle dung $+50 \%$ bagasse) took 36 day while the $100 \%$ bagasse treatments took the longest retention time of 40 day.

\section{Effect of heating times and partial heating under temperature of $175^{\circ} \mathrm{C}$}

Results for daily and accumulative biogas production at different heating times and partial heating for different fermentation mixtures at constant temperature of $175{ }^{\circ} \mathrm{C}$ are shown in Fig 2. The results showed that by increasing heating, daily biogas production increased.This result is attributed to the effect of heat on degradation of protein and complex carbohydrates bonds as well as chemical oxygen demand (COD) solubilization that led to enhancing biogas production. The results also indicated that increasing heating time to $40 \mathrm{~min}$, daily biogas production increased by $47.6,42.3$, and $20.6 \%$ for $100 \%$ C.D., $50 \%$ C.D. $+50 \%$ bagasse and $100 \%$ bagasse respectively comparing to control treatment.

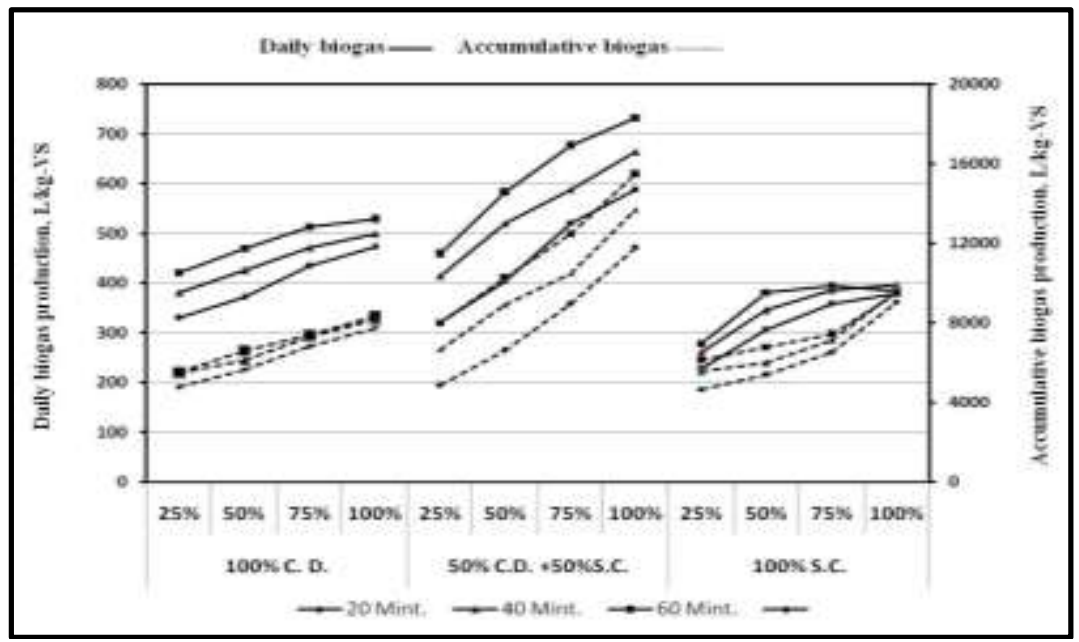

Figure 2: Effect of heating time and partial heating of samples on daily and accumulative biogas production at $175^{\circ} \mathrm{C}$ 
Meanwhile, increasing heating time to $60 \mathrm{~min}$, led to increase daily biogas production by $62.9,57.6$ and $29.4 \%$ under the same condition. This result is similar to (Pillia et al. 2015) where they said the optimum pretreatment time for increasing biogas production are in the range from 30 to $60 \mathrm{~min}$.

It can be noticed that by increasing partial heating percentage to $50 \%$, daily biogas production increased. These values reached 470.4, 582.1 and $381.5 \mathrm{~L} / \mathrm{kg}$ VS for $60 \mathrm{~min}$ heating time. The results revealed that heating $75 \%$ of the samples boosted biogas production to $98.8,130$ and $83.4 \%$ for 60 min heating time compared to control. This is due to dispersion of macromolecules that led to increase the surface area of the substrates that causing increase in biogas production (Protot $\boldsymbol{e t}$ al., 2011). It can be noticed that the maximum daily biogas production values for each mixture were 528.6, 732.4.5 and 383.9 L/kg VS for $100 \% \mathrm{CD}, 50 \% \mathrm{CD}+$ $50 \%$ BS and $100 \%$ BS under 60 min heating time and 100\% percentage heated because at higher temperatures, the substrate particles become finer. As a sequence of this, the surface area increases that led to better contact between substrate particles and the microorganism's population, thus more organic matter is converted into bio-methane.

Regarding the accumulative biogas production as shown in Fig. 2, the results showed that maximum accumulative biogas yield was 4860.4, 6616.6, 8958.9 and $11779.2 \mathrm{~L} / \mathrm{kg}$ VS for $50 \% \mathrm{CD}+50 \% \mathrm{BS}$ and decreased to $4673.8,5402.8,6548.2$ and $9065.1 \mathrm{~L} / \mathrm{kg}$ VS for $100 \% \mathrm{BS}$ under the four heating percentages and 20 min heating time. The reason for this increasing lignin content and lipid in bagasse made digestion activities more difficult for the microorganisms. Reduction in digestion activities of the microbes led to slow biogas production (Adelekan and Bamgboye 2009). The results indicated that accumulative biogas values increased to $43.6,92.4$ and $49 \%$ for $100 \% \mathrm{CD}, 50 \% \mathrm{CD}+50 \%$ BS and $100 \%$ BS under 40 min heating time compared to control for percentage heated samples 50\%. This result is similar to (Qiao et al. 2011).

\section{Effect of heating times and heated percentage under temperature of $200{ }^{\circ} \mathrm{C}$ :}

It was proved that increasing temperature from 175 to $200{ }^{\circ} \mathrm{C}$, daily biogas production increased for all treatments. The results indicated that 
the daily biogas production values were higher for $50 \% \mathrm{CD}+50 \% \mathrm{BS}$ compared to $100 \% \mathrm{CD}$ at $20 \mathrm{~min}$ heating. The $100 \% \mathrm{BS}$ gave the least values under the same conditions.

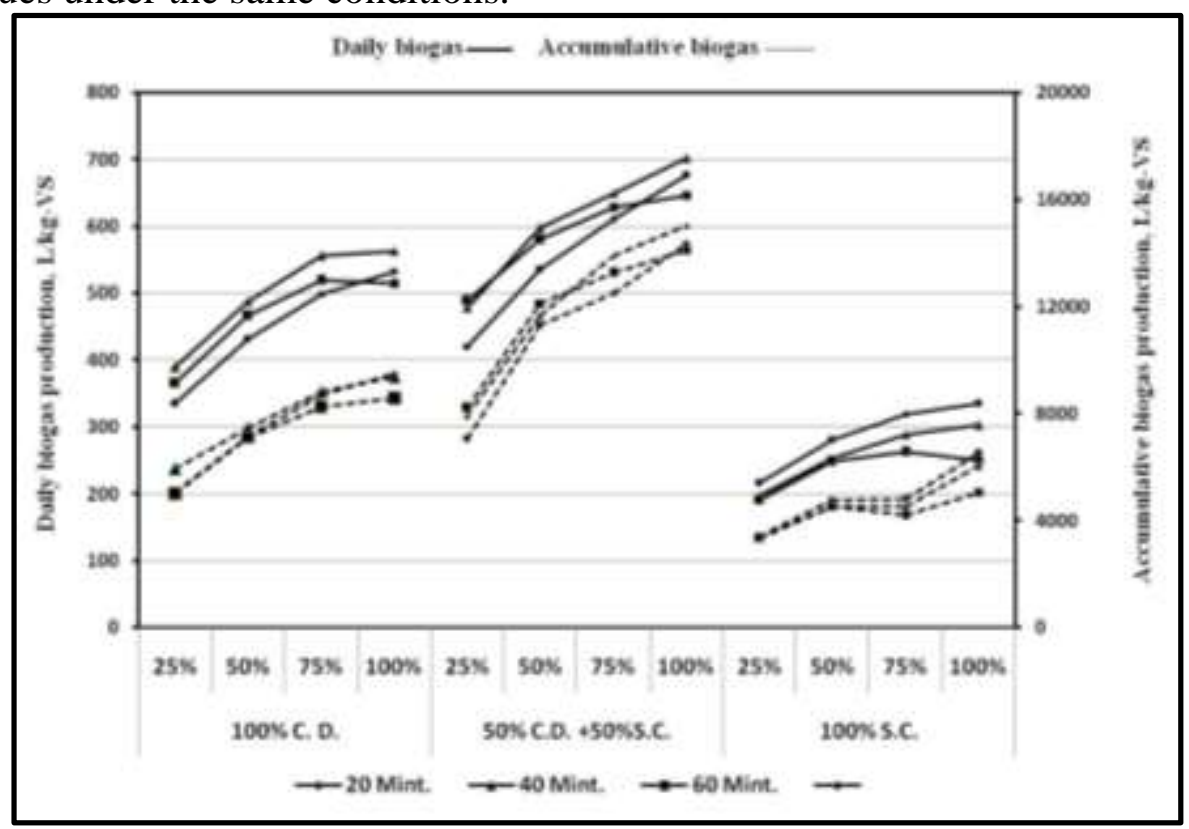

Figure 3: Effect of heating time and partial heating of samples on daily and accumulative biogas production at $200{ }^{\circ} \mathrm{C}$

The results ascertained that increasing thermal pretreatment temperature to $200{ }^{\circ} \mathrm{C}$, increased daily biogas production for $100 \% \mathrm{CD}$ and $50 \% \mathrm{CD}+$ $50 \%$ BS because higher temperature enhanced the biodegradable organic carbon by cracking the cell wall and releasing the intercellular matter in aqueous phase, which improves the digestion rates, reduces the hydraulic retention time, and increases the biogas production (Pilli et al., 2011). But these percentages decreased for the third mixture under the same previous conditions. This is because formation of toxic compounds and change in color produced that led to decreasing biogas production. In the other hand, the results showed that the values of daily biogas production under the second fermentation mixture decreased for $60 \mathrm{~min}$ heating time. This is due to high temperature with longer time responsible for the production of unmanageable soluble organics or toxic/inhibitory intermediates during the pretreatment process (Wilson and Novak 2009). 
Fig (3) shows accumulative biogas production for different fermentation mixtures and different heating time under thermal temperature of $200{ }^{\circ} \mathrm{C}$. The results showed increasing treatment temperature led to increase accumulative biogas values. The second mixture gave the highest values followed by $100 \% \mathrm{CD}$ while the $100 \% \mathrm{BS}$ gave the least values. The results indicated that increasing heated percentage to $100 \%$ accumulative biogas increased compared to other partial heating treatments.

3. Effect of heating time and heated percentage on daily methane production and biogas calorific value under temperature of $175^{\circ} \mathrm{C}$ : Daily methane production and biogas calorific values for different fermentation mixtures under different heating time and heated percentage of samples are shown in Fig. 4.

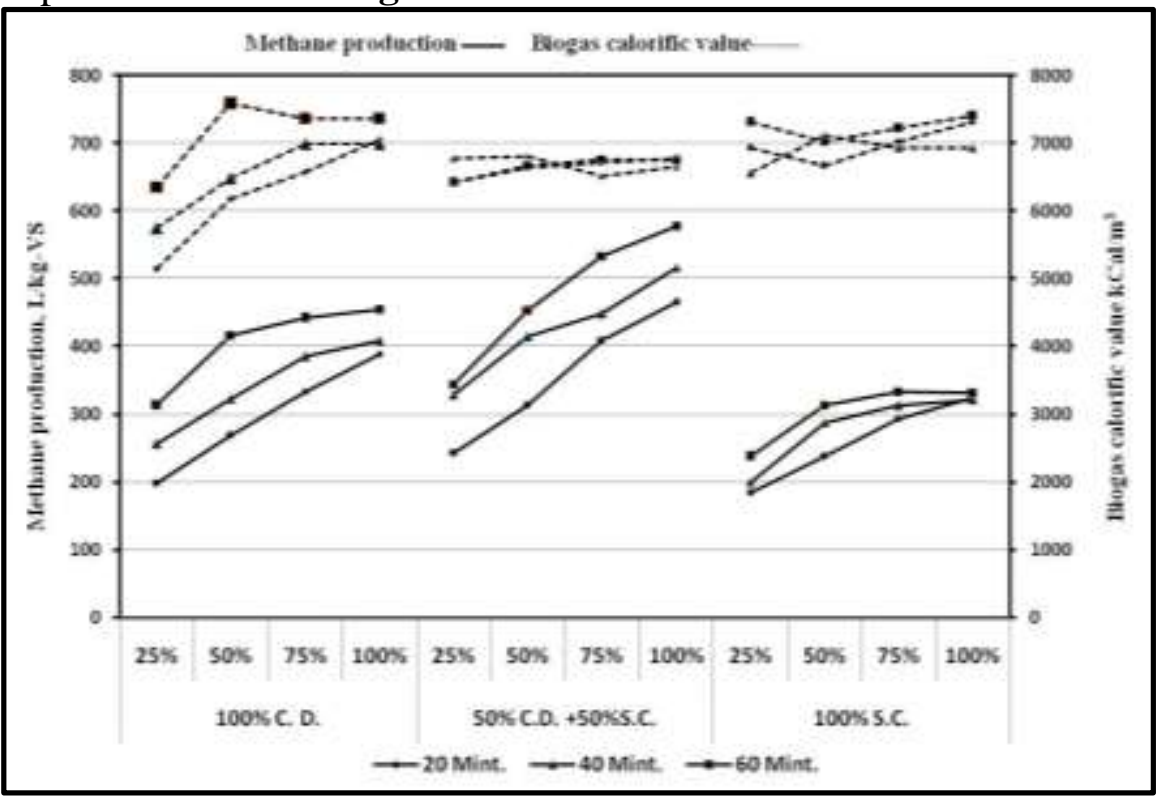

Figure 4: Effect of heating time and heated percentage of samples on daily methane production and biogas calorific value at $175^{\circ} \mathrm{C}$

The results indicated that mixing bagasse with cattle dung has a good impact on methane production. Also the results indicated that increasing heating time affected daily methane production positively. The $100 \% \mathrm{BS}$ treatment gave the least values. The reason for this low value in methane production is probably due to the fact that significant quantities of carbon dioxide and other non-combustible gasses were produced in the digestion of bagasse. 
4. Effect of heating time and heated percentage on daily methane production and biogas calorific value under temperature of $200^{\circ} \mathrm{C}$ :

The results illustrated in Fig. 5 indicate that there was positive effect on daily methane production when thermal temperature increased to $200^{\circ} \mathrm{C}$. That is because of high thermal temperature increasing volatile dissolved solids meaning the maximum percentage of substrate COD that is converted to methane.

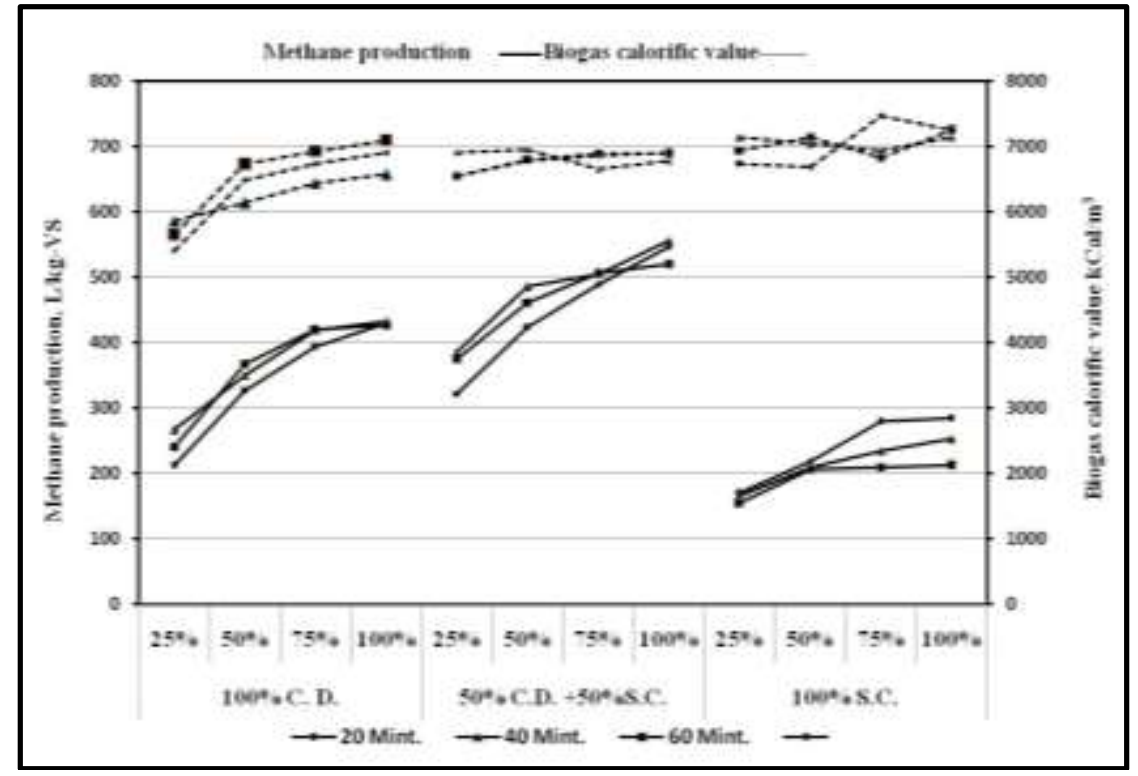

Figure 5: Effect of heating time and heated percentage of samples on daily methane production and biogas calorific value at $200{ }^{\circ} \mathrm{C}$

It can be noticed that daily methane production ranged from 155.2 to $555.9 \mathrm{~L} \mathrm{CH}_{4} / \mathrm{kg}$ VS. Results also indicated that increasing heating time to 60 min, daily methane production decreased. This is in agreement with (Bougrier et al. 2006) who reported that thermal pretreatment at high temperatures greater than $170^{\circ} \mathrm{C}$ led to the creation of chemical bonds and resulted in the agglomeration of the particles.

It is also worthy to notice that the biogas calorific value was highly affected by the thermal pretreatment of substrate. As Fig. 5 depicts the effect of substrate type and heated percentage on the produced biogas calorific value at $200{ }^{\circ} \mathrm{C}$, the maximum calorific value was 7241.7 $\mathrm{kCal} / \mathrm{m}^{3}$ for the third fermentation mixture $(100 \% \mathrm{BS})$ using temperature of $200{ }^{\circ} \mathrm{C}$ for $60 \mathrm{~min}$ and $100 \%$ heating of samples. 


\section{CONCLUSION}

From the obtained results and their discussion, it can be concluded that the maximum daily biogas production values for each mixture were 528.6, 732.4 and $383.9 \mathrm{~L} / \mathrm{kg}$ VS for $100 \% \mathrm{CD}, 50 \% \mathrm{CD}+50 \% \mathrm{BS}$ and $100 \%$ BS under 60 min heating time and $100 \%$ percentage heated samples. Also the maximum calorific value was $7241.7 \mathrm{kCal} / \mathrm{m}^{3}$ for the third fermentation mixture (100\% BS) using temperature of $200{ }^{\circ} \mathrm{C}$ for 60 min and $100 \%$ heating of samples.

According to the obtained results, it is recommended to use the $50 \% \mathrm{CD}$ $+50 \%$ BS with 60 min thermal treatment to produce maximum biogas yield. Also, it is recommended to use thermal pretreatment of wastes by a convenient method. It was suggested to build a suitable oven with enough capacity to thermally treat the wastes. This oven should use a cheap source of energy such as burning farm wastes.

\section{REFERENCES}

Abdel-Hadi, M. A. and S. A. M. Abd El-Azeem (2008). Effect of heating, mixing and digester type on biogas production from buffalo dung.Misr J. Ag. Eng., 25(4): 1454-1477.

Adelekan, B. A. and A. I. Bamgboye (2009). Comparison of biogas productivity of cassava peelsmixed in selected ratios with major livestock wastetypes. African Journal of Agricultural Research Vol. 4 (7), pp. 571-577, July 2009.

Adams, R. C.; MacLean, F. S.; Dixon, J. K.; Bennett, F. M.; Martin, G. I. and R. C. Lough(1951). The utilization of organic wastes in N.Z.: Second interim report of the inter-departmental committee. New Zealand Engineering (November 15, 1951):396-424.

Bakhov, Z.K.; Korazbekova, K. U. and K.M. Lakhanova (2014). The kinetics of methane production from co-digestion of cattle manure. Pak. J. Biol. Sci., 17: 1023-1029.

Bharathiraja, B.; Sudharsana, T.; Jayamuthunagai, J.; Praveenkumarc, R.; Chozhavendhan, S. and J. Iyyappan (2018). Biogas production A review on composition, fuel properties, feed stock and principles of anaerobic digestion.Renewable and Sustainable Energy Reviews 90 (2018) 570-582. 
Bond, T. and M. R. Templeton (2011). History and future of domesticbiogas plants in the developing world. Energy Sustain. Dev.,15: 347-354.

Bougrier C.; Albasi, C.; J.P. Delgenesand and H. Carrere (2006). Effect of ultrasonic, thermal and ozone pretreatments on waste activated sludge solubilization and anaerobic biodegradability, Chemical Engineering and Processing; 45: 711-718

Bougrier, C.; Delgenes, J. P. and H. Carrere (2008). Effects of thermal treatments on five different waste activated sludge samples solubilisation, physical properties and anaerobic digestion. Chem. Eng. J., 139: 236-244.

Ezekoye, V. A. and C. E. Okeke (2006). Design, construction, and performance evaluation of plastic biodigester and the storage of biogas. The Pacific Journal of Science and Technology, 7(2), 176-184.

Fehrenbach, H.; Giegrich, J.; Reinhardt, G.; Sayer, U.; Gretz, M.; Lanje, K. and J. Schmitz (2008).Criteria for a sustainable use of bioenergy on a global scale. Germany: N. p., 2008. Web. https://www.osti.gov/etdeweb/biblio/21240931

Garrote, G.; Dominguez, H. and J. C. Parajo (1999). Hydrothermal processing of lignocellulosic materials. HolzalsRoh- und Werkstoff 57, 191-202.

Gosch A.; Hildegart, M.; Ursula, W. and J. Walter (1983). The anaerobic treatment of poultry manure, Animal Res. and Dev., 17: 62-73.

GTZ-GATE (1999). Biogas Digest (Volume I. Biogas Basics) GTZ-GATE. Eschborn, Germany. http://www2.gtz.de/dokumente/bib/04- 5364.pdf

Higgins, M. J. and J. T. Novak, (1997). Characterization of exocellular protein and its role in bioflocculation. J. Environ. Eng., 123: 479485.

IPCC (2000). Special report on emission scenarios, Intergovernmental Panel on Climate Change

Jayashree, C.; Janshi, G.; Yeom, I. T.; Kumar, S. A. and J. R. Banu (2014). Effect of low temperature thermo-chemical pretreatment of dairy waste activated sludge on the performance of microbial fuel 
cell. International Journal of Electrochemical Science. 2014;9: 5732-5742.

Montgomery, L. F. R. and G. Bochmann (2014). Pretreatment of feedstock for enhanced biogas production. IEA Bioenergy 2014.

https://www.nachhaltigwirtschaften.at/resources/iea_pdf/reports/iea_bioe nergy_task37_study_pretreatment.pdf

Pilli, S., Puspendu, B.; Yan, S.; LeBlanc, R. J.; Tyagi, R. D.; and R. Y. Surampalli (2011). Ultrasonic pre-treatment of sludge: A review. Ultrasonics, 18, 1-18.

Pillia, S.; Yana, S.; Tyagia, R. D.; and R. Y. Surampallib (2015): Thermal Pretreatment of Sewage Sludge to Enhance Anaerobic Digestion: A Review, Critical Reviews in Environmental Science and Technology, 45:6, 669-702,

Protot A.; Julien, L.; Christophe, D. and L. Partick (2011). Sludge disintegration during heat treatment at low temperature: A better understanding of involved mechanisms with a multi-parametric approach. Biochemical Engineering Journal; 54: 178-184

Qiao, W.; Yan, X.; Ye, J.; Sun, Y.; Wang W.; and Z. Zhang, (2011). Evaluation of biogas production from different biomass wastes with/without hydrothermal pretreatment. Renewable Energy, 36: 3313-3318.

Salunkhe, D.B.; RAI, R. K. and R. P. Borkar (2012). BIOGAS TECHNOLOGY. International Journal of Engineering Science and Technology (IJEST).Vol. 4 No.12. 4934-4940

Tran, T. (2017). Standard Methods for the Examination of Water and Wastewater, $23^{\text {rd }}$ edition. 1545.

Weiland, P. (2010). Biogas production: current state and perspectives Applied Microbiology Biotechnology (2010) 85:849-860.

Wilson, C. and J. T. Novak (2009). Hydrolysis of macromolecular components of primary and secondary wastewater sludge by thermal hydrolytic pretreatment. Water Research. 2009;43:44894498 . 


\section{الملخص العربى}

\section{تحسين إنتاج الغاز الحيوى عن طريق معاملة المخلفات الزراعية حرارياً}

\section{عبدالله قشطة*، ريهام صبري فيض الله*** و علاء عونى}

تعانى الدول النامية من مشاكل كثيرة مثل مشكلة نقص الطاقة و انقطاع الكهرباء بالإضافة إلى

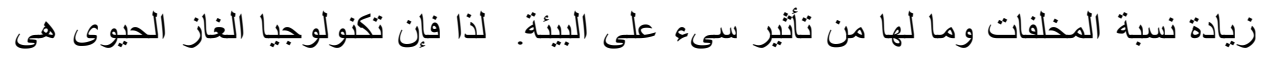

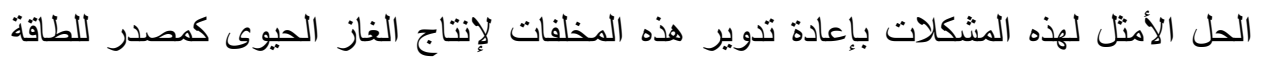
الحرارية. لذا كان الهدف من البحث إجراء بعض المعاملات الحرارية لتحسين جودة إنتاج الغاز الحيوى من المخلفات الزر اعية ودر اسة تأثثير خلط المخلفات على تحسين آداء آداء المخمر اتهات. تم إجراء بعض التجارب المعملية بكلية الطب البيطرى جامعة الزقازيق حيث تمثئ تم تصنيع

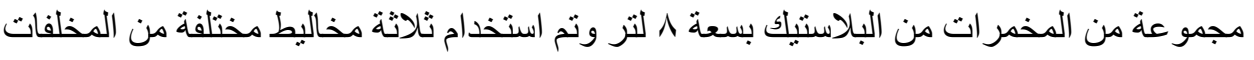

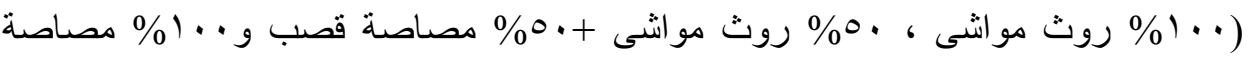

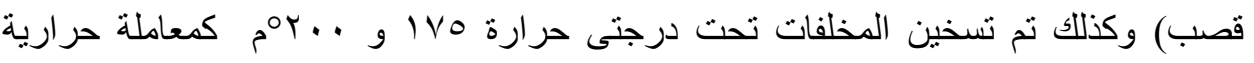

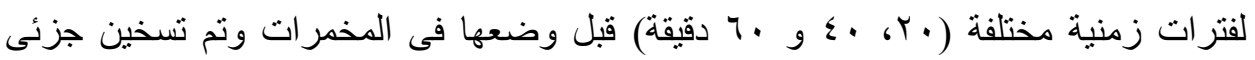

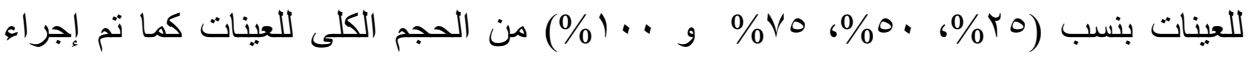

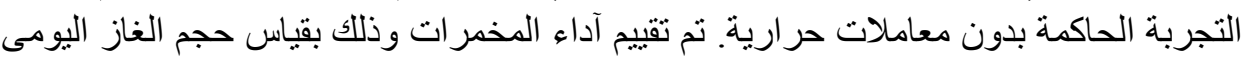
وحجم الغاز الكلى وكذللك جودة الغازمن خلال قياس حجم الميثان. كذللك تم تقدير القيمة الحرارية

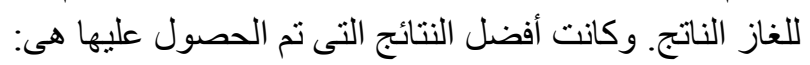

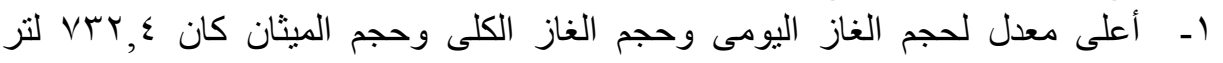

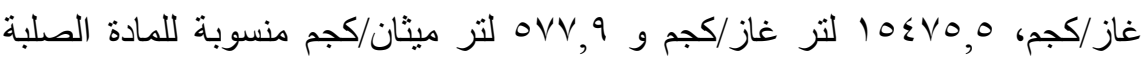

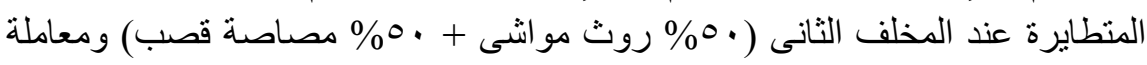

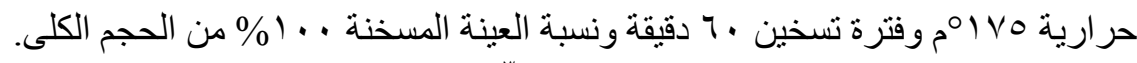

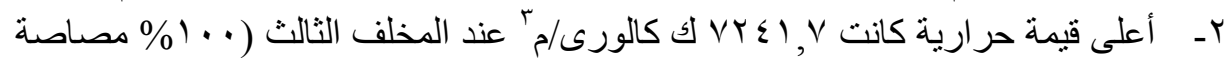

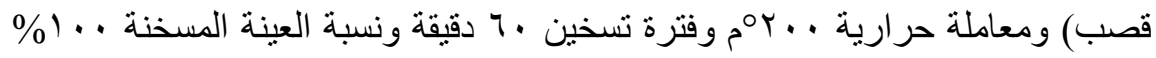
من الحجم الكلى.

لذلك يُوصى باستخدام المعاملة الحرارية للمخلفات من أجل تحسين آداء المخمر ات اللاهو ائية

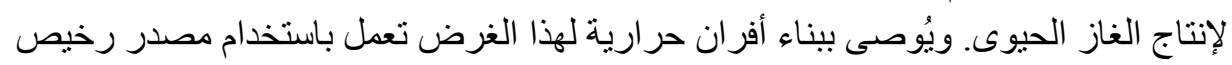

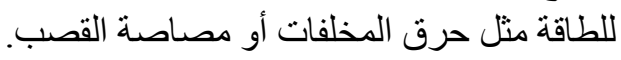

* أستاذ مساعد بقسم الهندسة الزراعية، كلية الزراعة، جامعة الزقازيق، الزقازيق، جمهورية مصر العربية.

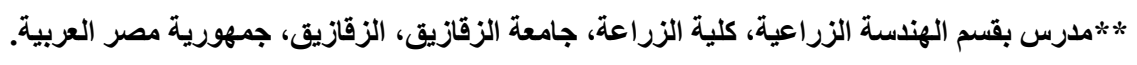

